\title{
The Implementation of Curriculum by Using Motion Pattern- Based Learning Media for Pre-school Children
}

\author{
Yusmawati $^{1}$ \\ Johansyah Lubis ${ }^{2}$ \\ Universitas Negeri Jakarta, Indonesia
}

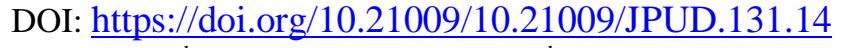

Accepted: $15^{\text {th }}$ March 2019. Published: $30^{\text {th }}$ April 2019

\begin{abstract}
This study aims to determine the implementation of curriculum in learning activities of pre-school children and develop motion pattern-based learning media for pre-school children. This research was carried out in thirty kindergartens in East Jakarta. It was conducted in 4 months, from June to October 2018. This research is included in the development and evaluation research (mixed method). The scope of the research is the implementation of curriculum and the development of learning media for pre-school children by using customized tools. Data was collected by using questionnaires and analyzed by using Guttman scale and Likert scale. Percentage of the implementation of learning for preschoolers in Kindergarten in East Jakarta is very good. The goal dimension got $98.2 \%$, the content dimension got $99.3 \%$, the method dimension got $99.3 \%$ and the evaluation dimension got $98.3 \%$. The product of this study is a learning media that is adjusted to the implementation of motion pattern-based learning activities for pre-school children.
\end{abstract}

Keywords: Early childhood education curriculum, Motion Pattern-Based Learning Media, Preschool children

(C) 2019 Early Childhood Education Post Graduate Program UNJ, Jakarta e-ISSN (Online Media): 2503-0566

P-ISSN (Print Media): 1693-1602

${ }^{1}$ Corresponding Author:

Yusmawati

Universitas Negeri Jakarta

Jln Rawamangun Muka. Jakarta Timur, Indonesia

Email: yusmawati@unj.ac.id 


\section{INTRODUCTION}

Curriculum is the most important part of continuity of the education process. Education and curriculum cannot be separated because they are interrelated. Education can succeed if it is well implemented. The curriculum will be updated as the time is changing. Therefore, the curriculum is always dynamic. Static curriculum is not good because it does not adjust to the current situation. The applied curriculum continues to evolve in line with the development of educational theory and practice based on the theory of education which is the curriculum reference prepared. In the process of compiling the curriculum, there are three concepts about the curriculum, curriculum as substance, as a system, and as a field of study (Sukmadinata, 2000, p. 27).

The first concept is the curriculum as a substance. The curriculum is seen as a plan of learning activities for students at school, or as a set of goals to be achieved. A curriculum can also refer to a document that contains the formulation of goals, teaching materials, teaching-learning activities, schedules, and evaluations. A curriculum is also described as a written document as a result of mutual agreement between curriculum compilers and educational policyholders with the community. A curriculum can also cover a certain scope, a school, a district, a province or an entire country.

The second concept is the curriculum as a system. The curriculum system is part of the school system, the education system, and the community system. A curriculum system includes a personnel structure and work procedures on how to compile a curriculum, implement, evaluate, and perfect it. The result of a curriculum system is the arrangement of a curriculum and the function of the curriculum system is how to maintain the curriculum so that it is permanent and dynamic.

The third concept is the curriculum as a field of study. This is the field of study of curriculum experts and education and teaching experts. The aim of the curriculum as a field of study is to develop knowledge about curriculum and curriculum systems. Those who study the curriculum, learn basic concepts about the curriculum. Through library research and various research and experimental activities, they find new things that can enrich and strengthen the field of curriculum study (Sukmadinata, 2000).

According to the previous perspective, the curriculum is a collection of subjects that must be delivered by the teacher or studied by students (Sukmadinata, 2000). In certain environments or relationships, this view is still used today, namely the curriculum as "... a racecourse of subject matters to be mastered." (Azia, 1976, p. 7). The curriculum is expressed as "a course, as a specific fixed course of study, as in school or college, as one field to a degree" (Webster, 1993, p. 648). Most parents, even educators, understand that the curriculum is a bigger part of the subject matter or subject matter.

Langgulung (1989, p. 145).stated that a curriculum is a number of educational, cultural, social, sports, and artistic experiences provided by schools for students inside and outside the school with the intention of helping them to develop thoroughly in all aspects and to change their behavior in accordance with their goals - educational goals. Meanwhile, according to Johnson, the experience will only appear if there is an interaction between students and their environment. Such interaction is not a curriculum, but teaching. The curriculum only describes or anticipates the results of teaching. Johnson distinguishes between the curriculum and teaching. Everything related to planning and implementation, such as content planning, teaching and learning activities, evaluation is teaching, while the curriculum is only concerned to the learning outcomes expected by students. The curriculum is a structured series of intended learning outcomes (Johnson, 1967, p. 130). 
The education system consists of four subsystems, they are learning, teaching, teaching-learning process, and curriculum (MacDonald, 1965, p. 3). Learning is an activity or effort carried out by students in responding teaching activities provided by the teacher. Teaching is an activity or professional treatment provided by the teacher. The whole linking of activities that allow and regard to the occurrence of teaching-learning interactions is called teaching-learning process. Curriculum is a plan that provides guidance in the process of teaching and learning activities.

The curriculum is perceived as a plan or program for all experiences which the learner encounters under the direction of the school. In Practice, the curriculum consists of a number of plans, in writing from and varying scope that delineates the desired learning experiences. The curriculum, therefore, may be a course, a sequence, of the school's entire program of studies and may take place outside of class or school when directed by personnel of the school (Olivia, 1992).

Planning before implementing learning is outlined in the curriculum. The curriculum is conceptually an activity plan or written document that includes strategies to achieve goals (Ornstein, 2004). Therefore, the curriculum can be interpreted as plans that will be implemented in learning and written into a document.

The document, which is later called the curriculum, will be the direction of learning in an institution. Basically, the curriculum is a planning guide regarding a comprehensive learning program that contains all learning experiences, learning materials adapted to the stages of child development that will be given to children through the learning process inside or outside the school is still under the supervision of the school. Curriculum that has been designed aims to provide teaching, nurturing and education to foster children's personality, as well as the development of other fields (Ayob, A., et al., 2016). In order to be able to develop experience and master the basic skill, it is needed to reach a higher level of knowledge and acquisitions so that they will be able to enter the next school level.

The learning process in an institution will be directed if it has clear guidelines. Guidelines for directing the process of implementing learning are outlined in the curriculum. Teachers as implementers of learning must understand curriculum concepts because the curriculum concept understood by the teacher will affect the learning process. An important component in implementing a lesson is the curriculum. The learning curriculum as an important element in the implementation of learning plays an important role in providing direction, steps, and objectives for implementing education (Cholimah, 2012). Therefore, the curriculum is absolutely necessary for the ongoing process of good learning. Curriculum and learning are packages that are interrelated with each other. The curriculum which is planning is meaningless if it is not implemented in the learning process. Learning cannot be implemented properly without curriculum guidance. "Without a curriculum or plan, there can be no effective instruction and instruction in the curriculum has little meaning" (Saylor, J. G., \& Alexander, 1981).

The process of making a curriculum has 6 steps; design, fostering, implementing, monitoring, evaluating and reviewing. After this process is implemented, a curriculum can be implemented thoroughly (Brady, 1995). John Dewey's progressive education theory has a strong influence in the 2013 early childhood education (ECD) curriculum. This matter is seen from Child-centered as a learning pattern policy. Dewey believes that the curriculum needs to be created by emphasizing children's interests and focusing on solving everyday children's problems (Morrison, 2012). The 2013 ECD curriculum is oriented towards the scientific approach. Preparation of curriculum 
content is a unified or concentrated curriculum. The unified or concentrated curriculum is a pattern of the preparation of learning materials that are composed of learning themes and in the theme includes material in various disciplines (Prihatini, 2014).

Johnson (1967) distinguishes between curriculum and curriculum development processes. The curriculum is the result of a curriculum development system, but the development system is not a curriculum. According to Johnson, the curriculum is a set of structured learning goals. The curriculum deals with goals and not with activities. Based on the formulation of the curriculum, children's learning experiences become part of teaching. The curriculum is the entire experience, activities, and knowledge of students through guidance and responsibility school or teacher. Understanding this curriculum has implications for school programs that all activities carried out by students can provide learning experiences.

These activities can include activities in the classroom. For example, activities in participating in the teaching-learning process (face-to-face), practice skills, and the like, or activities outside the classroom, such as scout activities, tourism works, visits to tourist attractions/history, the commemoration of national and religious holidays, and the like. In fact, all activities related to relationships between students and teachers, students with students, students with school officers, and students' own life experiences. The understanding of this curriculum contains broad coverage because it covers all student activities, student experience, and all influences, both physical and non-physical on the growth and development of students.

The curriculum is in the sense of meaningful learning plans with teaching. That is, the curriculum is a lot related to the plans and ideas to be achieved while teaching lies in the realization or implementation of the plan in teaching and learning activities. That is why curriculum development means the development of teaching. The difference between curriculum and teaching lies not in its implementation, but in the breadth of its scope. The curriculum is concerned to broader goals, content, and methods, while the narrower one is teaching. In other words, the curriculum relates to what you want to achieve (goals), while teaching is related to how to achieve that goal (procedure).

Ralph W. Tylor in Sukmadinata, (2000) suggests four main questions that are the core of curriculum studies: 1) which educational goals do you want to reach the school? 2) What educational experience should be provided to achieve this goal? 3) How to organize the educational experience effectively? 4) How to determine the goal that has been achieved? The existence of six curriculum components as a field of study; curriculum foundation, curriculum content, curriculum design, curriculum engineering, evaluation and research, and theory development (George A.Beauchamp, 1981).

Faix used structural-functional analysis derived from biology, sociology, and anthropology to explain curriculum concepts. The function of the curriculum is described as a process of how to maintain and develop its structure (Sukmadinata, 2000). There are a number of questions raised in this structural-functional analysis. The topics and subtopics of this question indicate the phenomenon of the curriculum. The questions concern about (1) general questions about the phenomenon of curriculum, (2) the curriculum system, (3) the unit of analysis and its elements, (4) the structure of the curriculum system, (5) the function of the curriculum system, (6) the curriculum process, and (7) structural-functional analysis procedures. There are four curriculum theories; they are (1) curriculum theory, (2) formal curriculum theory, (3) evaluation curriculum theory, and (4) phraseology curriculum theory. 
The curriculum has a central position in the entire educational process. The curriculum directs all forms of educational activities to achieve educational goals. The curriculum at every level of education must have been adapted to the character of students in general, especially in a kindergarten. But, how is the implementation of Learning Activities for Pre-School Children in Kindergarten - East Jakarta? How is the implementation of the Basic Motion Pattern Based Learning Model for Pre-Schools Children in Kindergarten in East Jakarta? Based on those reason, research and evaluation is needed. Evaluation or assessment is a systematic analysis to see the effectiveness of the program provided and the influence of the program on children (Rahelly, 2018). In order to accommodate the goals and needs of the physical and sports education movement, it is important to adapt to the level of education of pre-school children. Implementation of the Media Model in learning at pre-school requires creativity as an effort to achieve the objectives of the learning activities program.

\section{METHODS}

The study used a survey method. Survey research is a useful tool for discovering the facts of education (Kerlinger, 1990, p. 677). The study was conducted in the Kindergarten in East Jakarta. The target of this research was physical education teachers from each school, totaling 30 schools randomly. The data collection technique used a questionnaire with the instrument validated by the expert. The steps taken start setting the target of the survey, namely the physical education teacher recording each step of the research and making a final report. Data from four main components in the curriculum, namely objectives, contents, methods, and evaluations will be processed using the Guttman scale / dichotomy and using a Likert scale and percentage formula (Arikunto, 2010). A goal oriented is measuring the level of achievement of objectives in the implementation of physical education learning or activities.

\section{RESULT AND DISCUSSION}

Result

Children's activities in pre-school are evaluated on the curriculum dimensions or pre-school childhood education activities carried out. Evaluation is a systematic process for determining values based on data collected through measurements (Winarno, 2011). Arikunto (2014) defines evaluation as an activity to gather information about the workings of something which is then used to determine the right alternative in deciding. Furthermore, evaluation is a process or activity of selecting, collecting, analyzing and presenting information that can be used as a basis for decision making and subsequent programming (Widoyoko, 2012). The opinion above concluded that evaluation is data obtained from the results of measurements in order to provide information to be conveyed to decision-making about the effectiveness of program activities or curricula that are being or have been implemented.

The results obtained from the sub-dimensions of the objectives based on the instrument is $98.2 \%$ of the average value for the goal, while the results of the average value for the dimension of content is $99.3 \%$, while the results of the average value for the method dimensions are $95.6 \%$, while the average value for the evaluation dimension is $98.3 \%$, as stated in the following figure: 


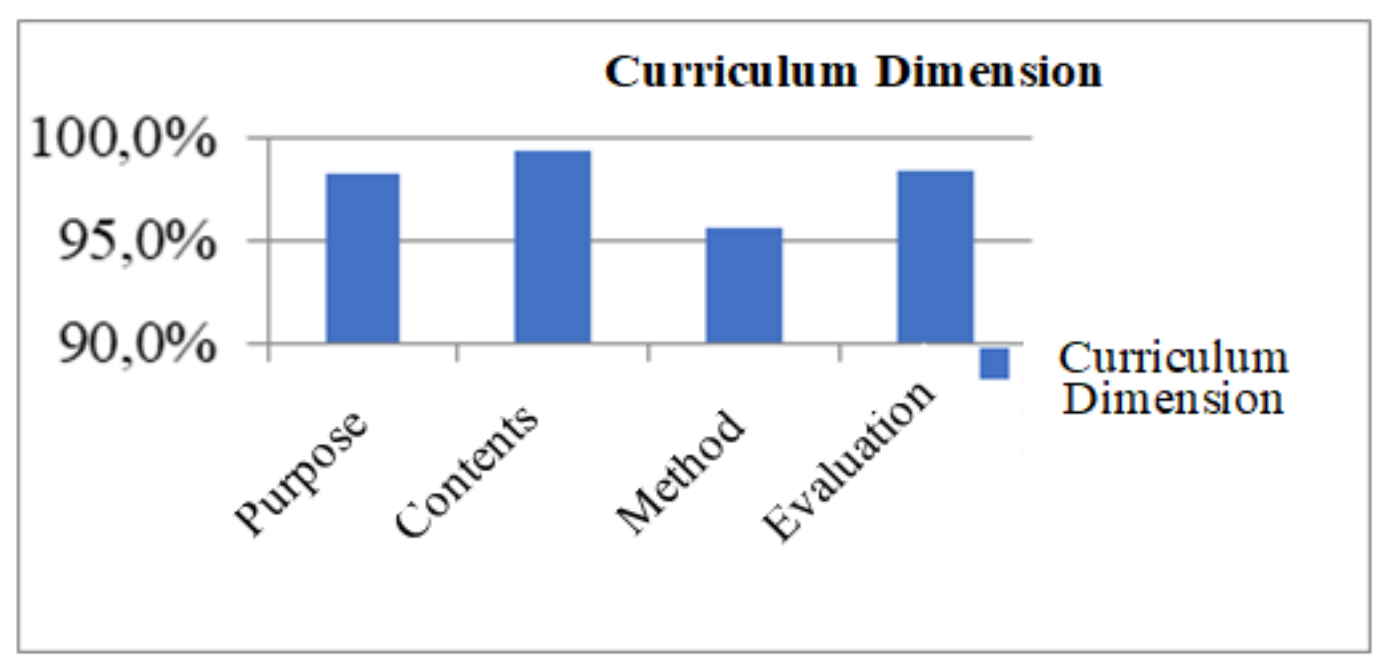

Figure 1. Curriculum Dimension

\subsection{Learning Media}

Media is one component of communication. It is a messenger from communicators to communication (Criticos, 1996). Based on these definitions, learning media is a supporting tool in the learning process to make it maximal. In the learning process, the media has a function as a carrier of information from the source (teacher) to the recipient (student). The method is a procedure to help students receive and process information to achieve learning goals (Rohmansyah, 2017). Thus, media functions in the learning process can be shown through pictures, as follows:
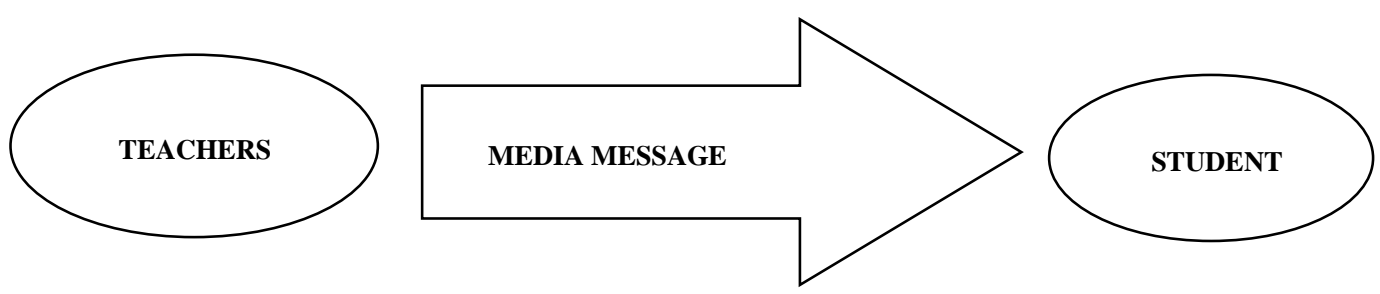

Figure 2. Media in Learning Process

Furthermore, as the media products produced are as follows: (1) Media Name: Moving, Playing, Exciting (2) Purpose: learn to do movements that use body parts to develop gross motoric through play (3) Form of Field: 


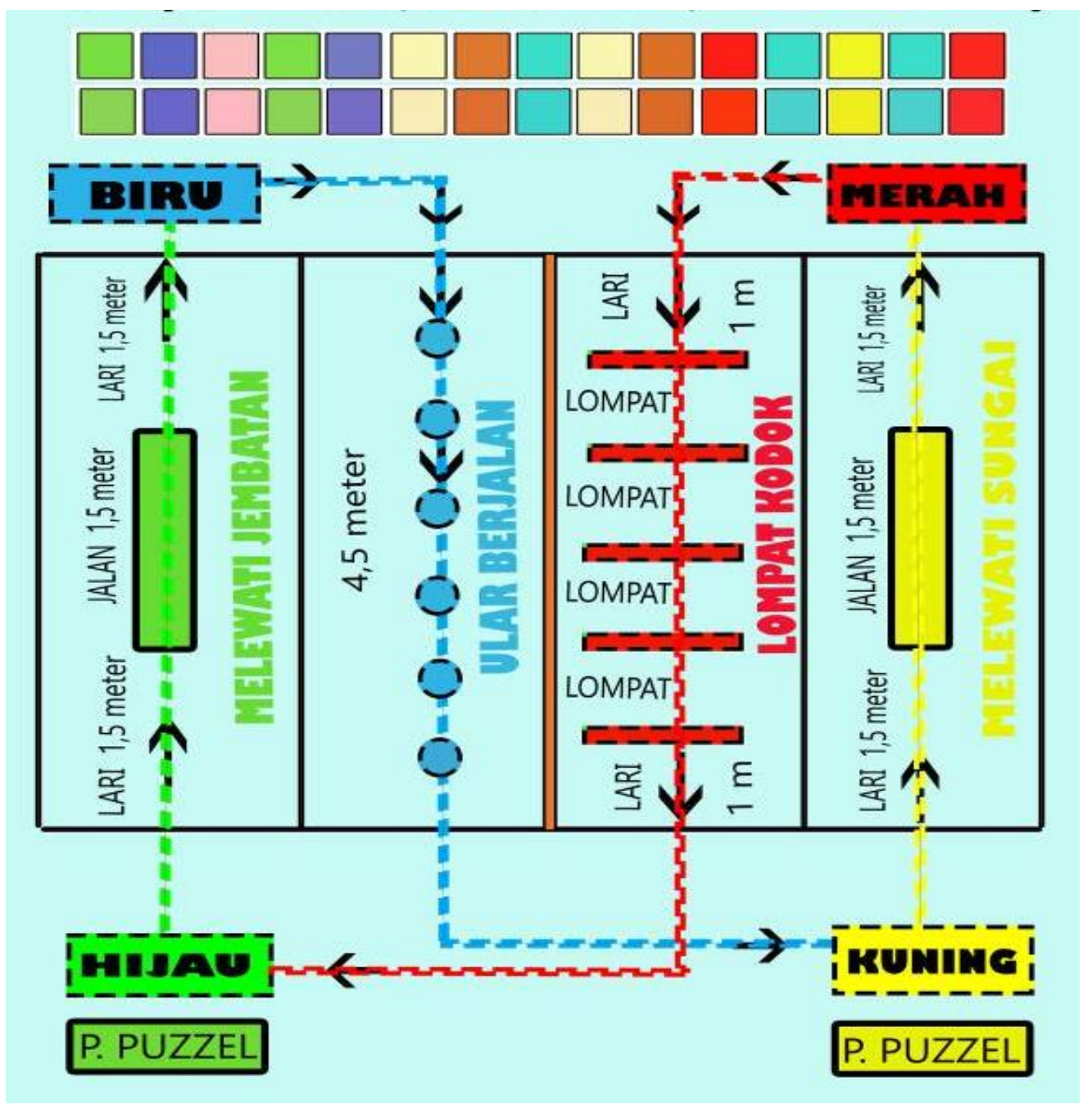

Figure 3. Learning Media

Figure color Information:

Green Line : Passing the bridge

Blue Line : Slithering snake

Red Line : Jumping frog

Yellow Line : Crossing the river

The Foundation for the Use of Learning Media which are:

\section{Philosophical Foundation}

With the existence of various learning media, students can have many choices for using media that are more suited to their choices. Students are given the freedom to choose both ways and learning tools according to their abilities.

\section{Psychological Foundation}

By paying attention to the diversity and uniqueness of the learning process, the accuracy of media selection and learning methods will greatly influence learning outcomes. In addition, student perceptions also greatly influence learning outcomes. Therefore, in addition to pay attention to the diversity and uniqueness of the learning process, understanding the meaning of perceptions of the factors that influence the presentation should be pursued optimally so that the learning process can take place effectively. For this purpose, it should be noted the following (a) The selection of 
the right media is held so that it can attract attention and give clarity to each object it observes. (b) Learning materials that will be applied are adjusted to experience.

\section{Technological Foundation}

Technological learning is the theory and practice of designing, developing, implementing, managing, and evaluating learning processes and sources. In learning technology, problem solving is done in the form of: the unity of the components of the learning system that has been compiled in the functions of design or selection and in utilization and combined so that it becomes a complete learning system.

\section{Empirical foundation}

Based on the empirical rational basis, the selection of learning media should not be based on the preferences of the teacher. However, it must consider the suitability between student characteristics, and the media itself.

\subsection{Characteristics of pre-school children}

Comprehensive understanding of pre-school children is needed to achieve the objectives of the research to be conducted. UNESCO defines Early childhood as the period from birth to 8 years old. A time of remarkable brain development, these years of funding for subsequent learning. From this definition, pre-school age is a period from birth to eight years when it is an important time span in brain development. In these years the next foundation of learning was built. Ki Hajar Dewantara said that children's education is important since early year. Personal formation of children is based on talent and environment.

Kindergarten is one of education units for pre-school children on formal education pathways that provide educational programs for children aged 4-6 years. Age 4-5 years is a sensitive period for children, where children begin to be sensitive to accepting various efforts to develop the full potential of children. Sensitive period is the occurrence of maturation of physical and psychological functions that are ready to respond to stimulation given (Jamaris, 2006). Children will learn well and meaningfully if children feel psychologically comfortable and their physical needs are met. Children construct their knowledge, learn through social interaction with other adults and children, exploration, searching, the use of learning through play, elements of differences in children's attention.

\section{Cognitive development}

In the concrete operational phase, the child's ability to think logically has developed, provided that the object that is the source of logical thinking is present in a concrete manner. This ability to think logically is manifested in the ability to classify objects according to their classification, sort objects according to their order, the ability to understand the views of others, and the ability to think deductively.

\section{Affective development}

Affective domain is the domain that deals with attitudes and values. This affective development includes the nature of behaviors such as feelings, interests, attitudes, emotions, and values. Some experts say that each person's attitude can be predicted if someone has a high level of cognitive 
power. The characteristics of affective learning outcomes will be seen in students in various behaviors, such as: attention in learning, discipline in following learning, high motivation to know more about things, and respect for others.

\section{Psychomotor Development}

Psychomotor development is related to skills or the ability to act after someone receives a certain learning experience. Psychomotor domains are domains that are related to physical activity, for example: Running, jumping, throwing, hitting, etc. These psychomotor learning outcomes are actually a continuation of the results of cognitive learning / understanding something and affective learning outcomes in the form of behavioral tendencies (Sutapa, 2014).

\subsection{The Concept of Motion Patterns for Pre-School Children}

The development of basic motion is a process of obtaining motion that is constantly evolving based on: The process of developing nerves and muscles which are also influenced by offspring, a result of previous motion experience, current motion experience, and motion described in relation to certain motion patterns.

Motion pattern is a simple movements that can be divided into three forms of motion as follows; (a) Locomotor motion, where certain part of body move in a particular direction. (b) Non-locomotor motion, where some part of body is moving up and down but the body does not move. (c) Manipulative motion is a skill movement to act for moving part of body.

\section{Locomotor Pattern}

Locomotor is a movement where certain part of body move in a particular direction. Locomotor movements such as: walking, running, jumping and throwing.

\section{Walk}

Walking is a movement to step up in all directions that carried out by someone. However, a movement that has not been noticed since an early year might cause abnormalities in walking in the future. Therefore, exercise in walking must be socialized by playing, both in small and large groups.

The development pattern of mastering walking is, (1) Children can move fast and in control with a slow or fast rhythm. (2) The shape of movement when two legs steping up. (3) Not straddling when approaching a straight line, the two soles of the feet narrows. (4) Increasingly automatic footstep makes children can walk like adults. Children can walk with well footstep swing and turn righ or left easily.

There are several things we can consider technically as follow:

\section{a. Strike}

When moving forward, there is a tendency to lean forward or backward. Therefore, keep the body upright. Shoulders do not lift when the hand swings to avoid quickly tiring the upper limbs.

b. Head

When walking, the head position is looking forward. Occasionally, it is permitted to shake the head to the left or right because such movements do not interfere with the speed of the walking motion. 
c. Feet

The footsteps straight forward one line with an imaginary line from the body of the walker / imaginary line between the two ends of the foot in line, not outward or inward. When it rests, the heel must touch the ground first and continue to move forward regularly.

d. Arms and shoulders

The arm motion swings from face to back and the elbow is bent not less than 90 degrees. This condition must be maintained and added by swinging relaxly without disturbing the balance.

Run

Running can be used by the teacher as a basis for giving exercise to students regularly. Teachers can take advantage of movement factors, such as place, time, and strength to create variations of running. Variations can also be created using bodily functions and part of body.

Running is not much different from walking; it is just going to be faster until the destination and movement one day floating in the air or rather jumping. Running movements can be driven by various combinations, for example:

a. Running by kicking your buttocks with your heels behind.

b. Running by raising your thighs high with a hand swing.

c. Running with steps hanging in the air.

d. Running with long steps and so on.

Various running activities, including:

1. Challenged running.

2. Reaction exercise by running.

3. Playing with running / chasing.

Jump

Jumping is a movement that lifts the body from one point to another that is farther or taller with a runner run fast or slow by laying on one leg and landing with the foot or other limbs in good balance.

Throw

Throwing is a movement to direct an object held by swinging your hand in a certain direction. This movement is done by using the strength of the hands and arms and requires coordination of several elements of movement, such as the arm with the finger that must release the object held at the right time.

\section{Non-locomotor Motion Patterns}

Non-locomotor motion does not move all the body. Only some part of body moved. The activities like: pushing, pulling, bending and twisting, twisting, shaking the hips and shoulders, and pulling.

\section{Manipulative Motion Pattern}

Manipulative skills involve the act of controlling an object especially by hands or feet. There are two classifications of manipulative skills, namely receptive and propulsive. Receptive skills are accepting an object such as capturing and propulsive skills having the characteristic of exerting force or force on an object, such as hitting, throwing, bouncing or kicking. Some movements 
included in manipulative movements are rolling balls or the like, throwing and catching, holding, reflecting and hitting.

\section{Discussion}

Implementation of the curriculum using motion patterns-based learning media, in general, has the same stages as other schools. However, the stages of learning in the implementation of this curriculum run a little different. Learning activities are dominated by providing optimal space for children in various types of activities carried out. The teacher gives children the freedom to move such as running, jumping, throwing, and the like.

The use of media motion patterns in the implementation of this curriculum aims to optimize all aspects of child development; cognitive, affective and psychomotor aspects. All aspects of development are trained using media based on motion patterns. Media based on the motion pattern of the child can be done indoors or outdoors.

Before the implementation of learning is carried out, the teacher will make a lesson plan that contains tomorrow's learning activities that content of using motion patterns. The teacher designs the types of activities, media, and tools that will be used. This is in accordance with the opinion of Sujiono (2009) that the curriculum is a very planned application so that the planning of the implementation of the curriculum based on motion patterns is an important part before the implementation of learning by the teacher. All aspects are considered by the teacher so that the activities carried out can optimize all aspects of development. For example, in the theme of plants, the pattern of motion that is carried out is the movement of hoeing, planting, watering, and so on. In addition, there are also trees, trees that are blown by gentle wind and trees that are blown by the strong wind. Cognitive aspects can be developed while children doing the motion patterns before the teacher introduce the word cards about the movements that will be carried out.

From the stages of learning that have been carried out, the teacher uses strategies in learning activities that are in accordance with the specific theme using motion patterns. The theme of learning implemented is always in accordance with the pattern of motion. The teacher gives children more freedom in movement which is designed through play-based learning (Kawaitouw, Widiastuti, \& Kurniawan, 2018). Although many children are given the freedom to play, teachers are required to be involved in a game of motion patterns, for example giving examples of motion patterns at the beginning of the activity.

Through the design of learning activities carried out by playing, children can build interest and foster feelings of pleasure before participating in class activities. Motion play activities can help children practice socialization with peers, make children creative by making new patterns of motion to be played, and develop language skills to communicate with their peers.

During outdoor activities, during the game, the teachers also participate in it. For example, when a child plays a pattern of crawling like a goat, jumping like a frog and throwing a ball into a container, the teachers also actively play with the children and follow the rules of the game such as waiting in line for their turn. So that the implementation of the curriculum based on the pattern of movement is not only done by children, but also by teachers. This implementation is also useful for teachers to move and exercise lightly which is often rarely done every day.

Implementation of the curriculum uses learning media based on the pattern of movement for preschool age held in kindergartens in East Jakarta. As the implementation of the curriculum, in general, begins with the preparation of Semester Program, Weekly Learning Lesson Plan, Daily 
Learning Implementation Plan, and Planning Evaluation. The process of implementing the curriculum that is carried out is using media motion patterns because pre-school children have more movement activity compared to the age above it.

The implementation of the curriculum using motion media is very dependent on the teacher. The curriculum can be implemented properly if the teacher is committed to implementing the curriculum (Rahelly, 2018). In addition, the competence and creativity of the teacher also determine the success of the implementation of the specific curriculum in the preparation of curriculum documents. Teachers who succeed in implementing the curriculum are able to choose and create a learning atmosphere that makes students excited, able to choose and implement teaching methods that are in accordance with students' abilities, able to learning the material and actively involve students. In addition, the teacher is able to choose, compile, and carry out evaluations, both to evaluate the development or student learning outcomes to assess the efficiency of the implementation itself (Winarso, 2017). It can be concluded that the implementation of the curriculum based on motion patterns can be implemented properly and optimize all aspects of child development.

The teacher is one of the important elements in the successful implementation of the curriculum. Teachers must be dynamic, relevant, and authentically connected with the profession they are engaged in (Boyle \& Phelps, 2010). The education curriculum must be designed by teachers to provide educational services for all students. Curriculum innovation based on motion patterns provides an example of a curriculum that can be achieved, giving opportunities to students to develop well. By expanding learning and learning environments that are designed collaboratively, are fun and involve active students

The curriculum implementation seeks to provide innovation approaches and methods in an effort to improve education (Ozturk, 2011). In the 2013 curriculum, it is possible and encourages teachers to take a greater role in the development of the learning process. The implementation of a curriculum based on motion patterns is one of the efforts made to make an innovation in the learning process. So that the 2013 curriculum objectives can be achieved in accordance with the expected targets. The implementation of a curriculum based on motion patterns introduces a new teaching method that focuses on the needs, interests, and demands of pre-school age children who are still very active and consider the diversity of children. This is done so that the relationship between teachers and students in the implementation of the curriculum can take place in two directions and involve students actively in learning.

\section{CONCLUSION}

The results of this study indicate the implementation of overall physical education learning showed a high percentage result. If all these dimensions are accumulated, they show very well. Thus, the implementation of educational learning is very effective in pre-school children in kindergarten. It has followed the 2013 curriculum for Kindergarten in East Jakarta. Obtaining data from research provides information that can be used in addressing the current schools for preschool age children and for teachers who will teach. Media provides a varied form of movement for students in physical learning. 


\section{REFERENCES}

Arikunto, S. (2010). Prosedur Penelitian Suatu Pendekatan Praktik. Jakarta: Asdi Mahasatya.

Arikunto, S. (2014). Prosedur Penelitian. Jakarta: Rineka Cipta.

Ayob, A., Badzis, M., \& Nordin, A. L.Abdullah, R. (2016). Kurikulum Permata Negara. Tanjong Malim: NCDRC, UPSI.

Azia, R. S. (1976). Curriculum Principles and Foundation. New York: Harper and Row Publisher.

Boyle, T., \& Phelps, R. (2010). Curriculum To Acknowledge Diversity. The International Journal of Learning, 17(2), 357-370.

Brady, L. (1995). Curriculum development (5th ed.). Sydney: Prentice-Hall.

Cholimah, N. (2012). Pengembangan Kurikulum PAUD Berdasarkan Permen 58 Tahun 2009.

Criticos. (1996). Media. Amazon.

George A.Beauchamp. (1981). Curriculum Theory. F.E. Peacock Publisher.

Jamaris, M. (2006). Perkembangan dan Pengembangan Anak Usia Dini Taman Kanak-kanak. Jakarta: Gramedia Widiasarana.

Johnson, M. (1967). Intentionality in Education. New York: Center for Curriculum Research and Services.

Kawaitouw, Y. I., Widiastuti, A. A., \& Kurniawan, M. (2018). Unit Studies Curriculum: Strategi Guru Dalam Implementasi Kurikulum di Jungle School Sidomukti. Jurnal Pendidikan Usia Dini, 12(November), 371-380.

Kerlinger, F. N. (1990). Asas-asas Penelitian Behavioral (3th ed.). Yogyakarta: Gajah Mada University Press.

Langgulung, H. (1989). Manusia dan Pendidikan: Suatu Analisa Psikologik dan Pendidikan. Jakarta: Pustaka al-Husna.

MacDonald, J. B. (1965). Educational Models for Instruction. Washington DC: The Association for Supervision and Curriculum Development.

Morrison, G. S. (2012). Dasar-dasar Pendidikan Anak Usia Dini. Jakarta: Indeks.

Olivia, P. F. (1992). Developing the Curriculum (Third Edit). New York: Harper Collins Publishers Inc.

Ornstein, A. C. (2004). Curriculum:Foundation, Principles, and Issues. Boston: Pearson Education, Inc.

Ozturk, I. H. (2011). Curriculum Reform and Teacher Autonomy in Turkey: the case of the History Teaching". International Journal of Instruction, 4 (2)(2), 113-127.

Prihatini, P. (2014). Kajian Ide Kurikulum 2012 PAUD dan Implikasinya dalam Pengembangan KTSP. Cakrawala: Jurnal Pendidikan Anak USia Dini.

Rahelly, Y. (2018). Implementasi Kurikulum 2013 Pendidikan Anak Usia Dini di Sumatera Selatan. Jurnal Pendidikan Usia Dini, 12(November), 381-390. https://doi.org/https://doi.org/10.21009/JPUD.122.19

Rohmansyah, N. A. (2017). Pengaruh Model Pembelajaran Problem Based Learning Terhadap Kemampuan Pemahaman Konsep Pendidikan Jasmani Pada Pembelajaran Tematik Terintegrasi Siswa Kelas IV. JURNAL PENJAKORA, 4(28-35).

Saylor, J. G., \& Alexander, W. M. (1981). Curriculum Planning for Better Teaching and 
Learning. Holt-Rinehart and Winston.

Sujiono, Y. N. (2009). Konsep Dasar Pendidikan Anak Usia Dini. Jakarta: Indeks.

Sukmadinata, N. S. (2000). Pengembangan Kurikulum Teori dan Praktek. Bandung: Remaja Rosdakarya.

Sutapa, P. (2014). Pengembangan Model Pembelajaran Pendidikan Jasmani Berbasis Kinestetik Untuk Anak Usia Pra Sekolah. Yogyakarta.

Webster. (1993). Webster's New International Dictionary. GC Company.

Widoyoko, E. P. (2012). Evaluasi Program Pembelajaran. Yogyakarta: Pustaka Pelajar.

Winarno. (2011). Winarno. Metodologi dalam Penelitian Pendidikan Jasmani. Malang: Media Cakrawala Press.

Winarso, W. (2017). Dasar Pengembangan Kurikulum Sekolah, (January 2015). 